CATALLAXY

Volume 6 Issue 1 June 2021

e-ISSN 2544-090X

¿ www.catallaxy.pl

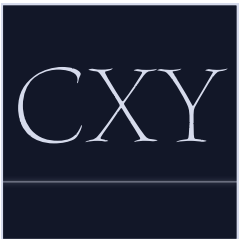

Original article

received: 20.04.2021 / accepted: 20.06.2021 / published online: 30.06 .2021

()ㅜㅇ

Grąbczewska, K. (2021). The relationship of marketing communication and customer behaviour in the online store industry. Catallaxy., 6(1), 19-27. https://doi.org/10.24136/cxy.2021.002.

\title{
The relationship of marketing communication and customer behaviour in the online store industry
}

\author{
KATARZYNA GRĄBCZEWSKA \\ Nicolaus Copernicus University in Torun, Faculty of Economic Sciences and Management, ul. Gagarina 13a, 87-100 Torú, \\ Poland \\ ⓚatarzynagrabczewska2@gmail.com \\ (iD) orcid.org/0000-0002-0610-1318
}

\begin{abstract}
Motivation: The article fills a crucial gap in the literature in the realm of investigating and understanding customer behaviour in the digital environment. Research in the field of ever-shifting digital marketing communication is fundamental.

Aim: The key purpose of the research paper is to investigate the relationship between the frequency of seeing marketing messages by respondents and their market behaviour.

Materials and methods: Various approaches to online marketing communication and descriptions of consumer behaviour were analysed in the theoretical framework of the article. The goal mentioned above was achieved through the survey conducted in 2020 on the sample of 461 respondents who had access to the Internet. Data were collected using a Google Form, and then the empirical data were analysed using Spearman's correlation coefficient in Microsoft Excel application. The research involved observing the online marketing communication carried out by the surveyed entities in addition to mentioned methods.

Results: The findings prove that the frequency of seeing marketing content by respondents has an impact on the Spontaneous Brand Awareness Rate, the Aided Brand Awareness Rate, the frequency of store website visits, the propensity to repurchase, and online store reviews. There is a strong relationship between the quantity and the variety of online marketing messages broadcasted by an online store and the engagement of customers in the digital activity of the online store. The research will help entrepreneurs develop future online marketing communication strategies and indicate the development of online communication toolkits. The research paper confirms the importance of maintaining a relationship with customers who shop online.
\end{abstract}

Keywords: online store; marketing communication; customer behaviour; digital marketing; brand awareness JEL: A12; A13

\section{Introduction}

Nowadays, many enterprises operate on the Internet. Considering the situation the entire world finds itself since 2020, it can be argued that the coronavirus pandemic has forced changes in businesses. Even successful companies with a significant market position have encountered different problems resulting from the global crisis. Digitalization came to help them. The communication that uses digital solutions becomes an essential process 
that allows maintenance contact between an organization and its environment (Izakova et al., 2021, pp. 1-2).

As a result of the Author's bachelor's thesis, it turned out that the most significant part of the respondents follows online store profiles on Facebook. In the second place were artists' profiles and then stationary store profiles. As most people follow online store profiles and the e-commerce market is increasing, it is vital to assess how entrepreneurs can influence customer behaviour, making it beneficial for their companies (Grąbczewska, 2019, p. 40). Moreover, observing the online shops, you can see the phenomenon of the footwear industry. It turns out that Europeans spend more on shoes than the rest of the world. Additionally, it is Poland that is recognized as one of the largest footwear manufacturers in the European Union (Żurek, 2020).

The Internet has changed some areas of traditional marketing into digital ones. One instance is a marketing communication that generally aims to maintain contact between the organization and the environment. Transferring this to the Internet space brings many benefits. There is a prospect of giving feedback rapidly after receiving messages from a customer. Undoubtedly, we are overwhelmed by lots of information today, which makes us get them quickly. Nevertheless, customer service staff do not have to stay near to the computer or other equipment with an Internet connection all the time to respond to clients immediately. There is an array of robots that can send first answers to customers depending on the received messages. Therefore, it would seem that maintaining a relationship with customers is straightforward (Xu et al., 2017, p. 3506).

Based on the aforementioned discussion, the author has analysed the relationship between marketing communication and customer behaviour in the online store industry (the footwear store sector was chosen for the research). It was the main aim of this paper. The theoretical framework includes consideration of various approaches to online marketing communication and customer behaviour descriptions. The empirical part presents obtained results of the conducted survey. To achieve the purpose mentioned above, Spearman's correlation coefficient was used. Besides that, the author has made observations of surveyed online stores' online marketing communications.

\section{Literature review}

There still exist gaps in research on digitization in the field of marketing communication. It is an area that is dynamically developing, so to keep up with that progress, these phenomena should be studied on an ongoing basis from different sides (Idrysheva et al., 2019, p. 2).

One of the areas that primarily draws on digital marketing is online stores. Their social media profiles are among the most frequently visited sites (Grąbczewska, 2019, p. 40). These are companies directly related to digitization. Their primary activity is based on IT solutions. Contact with the customer is usually done online. Therefore marketing communication should be based on solutions offered by digitization (van Riel et al., 2004, p. 6).

\subsection{Marketing communication}

According to Doyle (2011, p. 84), marketing communication is one of the principal components of the marketing mix. Together with new products appearing on the market, it becomes even more critical because it leads to bolster brand authenticity (Hoberg et al., 2014 , p. 295). The intensified market competition involves care of customers. Nowadays, the key marketing communication channel is social media. It plays a significant role in customers' engagement in company life, allowing them to spread information quickly (Abdul Ghani et al., 2020, pp. 43-44).

People use information and communication technologies (ICT) for different actions. They search for daily news, maintain contact with family and friends, sell and purchase various products or sites, search for opinions, 
give feedback about products and services, run their finances, and even manage jobs via them (Dwivedi et al., 2020, p. 1). Customers use technologies every day thus enterprises should draw attention to the above and treat ICT as the remarkable point that can be given to marketing communications.

\subsection{The Spontaneous Brand Awareness Rate}

Consumers that are cleaved to the brand more willingly purchase its products and services. One of the indicators that can help in assessing this phenomenon is the Spontaneous Brand Awareness Rate. This indicator reflects the percentage of respondents who spontaneously and without any suggestion mention the brand's name. It identifies the size of the mark that the brand has made in the customer's mind. The higher value of the rate, the better brand is known by respondents (Drumond, 2017, p. 26).

Brand awareness plays a significant role in customer decision-making. Its high value means that people think about a particular brand when they think about the category of product (Keller, 1993, p. 3). High brand awareness reduces the customer's perceived risk and makes them more willing to acquisition. There is a group of customers who only buy products made of brands they know well. Some clients are even willing to pay a higher price for quicker decision-making and thus reduced effort (Patil, 2017, pp. 16-17).

\subsection{The Aided Brand Awareness Rate}

The Aided Brand Awareness Rate works similarly to the beforementioned indicator. It shows the result of comparing the number of respondents who chose the particular brand from the list and the total sample size. The difference is that respondents in the Aided Brand Awareness survey are given specific brand names from which they choose the ones they know. They do not write names themselves (Keller, 1993, p. 12).

According to Moisescu (2009, pp. 103$110)$, most customers prefer to buy products made of the brand they have heard about. Additionally, as regards products of little-known brands, people are more willing to acquire non-durable goods than durables. Compared to the previous one, this rate shows if the brand leaves a smaller footprint in people's minds. However, this does not exclude that the brand is also known and associated by the audience.

\subsection{The frequency of store website visits}

When the company's activity is based on the web space, one of the critical variables (if not the most important) that leads to success is visiting the company's website by Internet users. Such a platform is a space that creates a replacement for a company's headquarters or its brick-and-mortar shop. Thus, it is worth taking care of the number of page visiting and scrutinizing elements such as sources of visiting the website, demographic data of visitors, or the number of people who turned off our website right after it was turned on (this can be verified via Google Analytics) (Strzelecki, 2014).

Knowledge about the effects that are achieved due to the website can significantly improve future activities. The company will get relevant clues about the areas that need to be strengthened, and above all, it allows to get to know whether its website is attractive enough (Ławrowski, 2020, p. 26).

\subsection{The propensity to repurchase}

When considering repurchase, it should be noted that it is closely related to customer loyalty. Customer loyalty towards e-commerce companies is called e-Loyalty, and it means customer's involvement and favourability towards those companies (Lam et al., 2003, pp. 309-311). In addition to making repeated purchases, loyal customers also persuade other people to take advantage of the store offer and thus increase the organization's income (Chen, 2012, pp. 207-209).

People who are firmly attached to the company regularly repeat purchases in its online store, even without analysing other companies' 
offers (Shafiee \& Bazargan, 2018, p. 30). They are one of the most valuable resources capital that a company can acquire. They ensure regular income for the organization and diffuse positive opinions about the brand, providing a free and reliable advertisement (Niepewna, 2021).

\subsection{Online store reviews}

It is commonly known that people would purchase from stores that they trust. This was confirmed by Utz et al. (2012, pp. 49-50) in the study. It turned out that customer reviews are even more essential to a company's reliability than its overall reputation and assurance seals. Consumers' reviews play a significant role in decision-making.

It has also been evidenced that positive opinions contribute to sales increasing, and negative opinions contribute to sales decreasing (Chevalier \& Mayzlin, 2006, pp. 345-354; Dellarocas et al., 2007, pp. 2-20). The above-mentioned arguments prove the essence of ensuring that customers have some space on the Internet for posting reviews.

\section{Materials and methods}

The paper aims to investigate the relationship between the frequency of seeing marketing messages by respondents and their market behaviour. Thus, a comprehensive methodology for assessing that was used.

A descriptive method was based on theoretical sources and materials of various authors. It allows the author to identify relevant variables that form the concept named customer behaviour. The methodology also includes quantitative research that analysed relationships between the frequency of seeing marketing content by respondents and the following:

- the spontaneous brand awareness;

- the aided brand awareness rate;

- the frequency of store website visits;

- the propensity to repurchase;

- online store reviews.
Respondents answered questions concerning mentioned facets via an online survey shared by the author on social media. According to Microsoft Excel, the collected data were examined, where the author counted Spearman's correlation coefficient for each relationship. Finally, the paper also presents the observation result as a comparison of the online marketing communication carried out by the surveyed entities. The entities had been chosen according to Google Search Engine position: four entities from the top of the search list (Czasnabuty.pl, Eobuwie.pl, Deezee.pl, Runcolors.pl) and four entities from worse positions (Buu.pl, Sellyo. pl, Aspena24.pl, Goodshoes.pl) so that it was possible to compare brands from different positions.

\section{Results}

Data were collected from November 2020 to December 2020. The sample consisted of 461 respondents. The vast majority (425) were women, and the others were men (36).

Firstly, respondents were asked about their frequency of purchasing online at all. As it turns out, $52.93 \%$ of respondents do it several times a month. The second largest group were respondents who shop online several times a year (26.68\%). $17.14 \%$ of respondents at least once a week, $1.52 \%$ of respondents do it just once a year, $0.43 \%$ of the sample did it only once in a lifetime, and $1.30 \%$ of respondents said they have never made purchases online. Before closed-ended questions, respondents were asked to list all online footwear stores that come to their mind. This way, the author examined spontaneous awareness of brands. Then, the respondents were asked the following questions about surveyed online stores:

- Do you know (store name) online store, at least from hearsay?

- How often do you meet the marketing messages of the (store name) online store?

- How often do you visit (store name) online store?

- Do you have at least one product purchased in (store name) online store? 
- Who made a purchase in (store name) online store most often?

- Will you decide to buy again in (store name) store?

- Please tick if you agree with the following statements relevant to (store name) online store: This store has a wide offer; The offer of this store meets my needs; I would recommend this store.

The above questions made it possible to rank the examined elements and then calculate the correlation between the frequency of seeing marketing messages and other variables that comprise the consumer behaviour.

Table 1 presents amounts of Spearman's correlation coefficient. It can be concluded that each element of customer behaviour is strongly associated with the frequency of seeing marketing content by recipients. The greater the intensity of marketing messages, the better the opinions about the store and the more willingly purchases are made in it. The high frequency of seeing brand messages leaves a strong mark on respondents' minds and makes them associate the brand name with the industry shoe store without any hints.

The study also includes the observation of online marketing communication carried out by the surveyed online stores. The results are given in Table 2.

According to the author's observations, all the stores mentioned above have an account on a popular social network, i.e. Facebook. Deezee.pl has the highest number of fans $(1,358,679$ fans). The store publishes over 33 posts per week. Such activities build a community. It is worth noting that $69 \%$ of the respondents know this store.

All surveyed stores have the option to subscribe to the newsletter, but Sellyo.pl and Aspena24.pl do not offer any additional benefits for joining. Lack of incentive can lead to a lack of customer interest in the newsletter, thus weakening the communication between the organization and the consumer. It is worth noting that these two stores are the least known among the respondents. Most people have not even heard of their existence.
The most famous store turned out to be Eobuwie.pl. Only 5\% of respondents do not know this store. Eobuwie.pl has 409,001 fans, and almost 11 posts a week are posted on its profile. When comparing this store with Deezee.pl (which, despite the larger number of posts and the larger number of fans, is less recognizable), it is worth considering whether the number of posts may be the only indicator. In subsequent studies, the quality of posts posted by stores should be analysed.

Looking at word of mouth, it can be seen that the most positive feedback has Goodshoes.pl, which is not one of the most popular stores. This issue should also be examined more closely, e.g., the quality of the services provided.

\section{Conclusion}

Nowadays marketing communication based on social media which engage consumers in companies' life. Thanks to social media, information spreads very quickly. Customers use these technologies every day; thus companies should consider them as great communication tools.

Brand awareness is very important in customer decision-making. It shows whether consumers know the brand well. Spontaneous Brand Awareness Rate allows to assessing consumer loyalty to the brand. Some customers buy products made of brands they know well only, and sometimes they are willing to pay more for that.

Online stores are a kind of substitute for a stationery stores. Tracking statistics allows getting valuable advice for future activities.

Building consumer loyalty affects the propensity to repurchase. Loyal customers provide the company with regular income by choosing their favourite brand every time they need to make purchases.

The Internet has created a new space for customers. Issuing an opinion is simple now. Organizations should follow their customers' feedback on the Internet and react to them as soon as possible because the negative feedback conducts a drop in sales. 
The study showed a strong correlation between the frequency of messages seen by respondents and their behaviour. The more marketing messages a store sends out, the better its reputation and sales. Numerous messages mark the audience's minds and make them able to recall the brand name from memory. Few posts on Facebook and no reward for joining a newsletter can make a store fail to build a lasting relationship and become less popular.

Future research is needed to analyse the quality and content of posts published on social media and their correlation with the popularity of the particular brand. Subsequent studies should also investigate the relationship between the quality of services provided by companies and feedback concerning them available on the Internet.

\section{References}

Abdul Ghani, W.S., Azman, N.A.A., Mohd Rashid, N., \& Abdul Halim, A.H. (2020). The relationship of brand marketing communication and brand authenticity. Journal of International Business, Economics and Entrepreneurship, 5(1), 43-49.

Aspena24.pl fan page. (2021). Retrieved 02.02.2021 from https://www.facebook.com/aspena24.

Aspena24.pl website. (2021). Retrieved 02.02.2021 from https://aspena24.pl.

Buu.pl fan page. (2021). Retrieved 02.02.2021 from https://www.facebook.com/BUUpl.

Buu.pl website. (2021). Retrieved 02.02.2021 from http://buu.pl.

Ceneo.pl. (2021). Opinions about Sellyo.pl. Retrieved 02.02.2021 from https://www.ceneo.pl/sklepy/ sellyo.pl-s14632.

Chen, S.C. (2012). The customer satisfaction-loyalty relation in an interactive e-service setting: the mediators. Journal of Retailing and Consumer Services, 19(2), 202-210. https://doi. org/10.1016/j.jretconser.2012.01.001.

Chevalier, J.A., \& Mayzlin, D. (2006). The effect of word of mouth on sales: online book reviews. Journal of Marketing Research, 43(3), 345-354. https://doi.org/10.1509/jmkr.43.3.345.

Czasnabuty.pl fan page. (2021). Retrieved 02.02.2021 from https://www.facebook.com/ czasnabuty.
Czasnabuty.pl website. (2021). Retrieved 02.02.2021 from https://www.czasnabuty.pl.

Deezee.pl fan page. (2021). Retrieved 02.02.2021 from https://www.facebook.com/DeeZeepl.

Deezee.pl website. (2021). Retrieved 02.02.2021 from https://deezee.pl.

Dellarocas, C., Zhang, X.M., \& Awad, N.F. (2007). Exploring the value of online product reviews in forecasting sales: the case of motion pictures. Journal of Interactive Marketing, 21(4), 23-45. https://doi.org/10.1002/dir.20087.

Doyle, Ch. (2011). A dictionary of marketing. Oxford University Press. https://doi.org/10.1093/ acref/9780199590230.001.0001.

Drumond, D.S. (2017). An assessment of how brand awareness influences brand recognition through product placement, applied to the automotive industry and computers. [Master's thesis, ISCTE Business School, Lisbon].

Dwivedi, Y.K., Rana, N.P., Slade, E.L., Singh, N., \& Kizgin, H. (2020). Editorial introduction: advances in theory and practice of digital marketing. Journal of Retailing and Consumer Services, 53, 101909. https://doi.org/10.1016/j. jretconser.2019.101909.

Eobuwie.pl fan page. (2021). Retrieved 02.02.2021 from https://www.facebook.com/eobuwiepl.

Eobuwie.pl website. (2021). Retrieved 02.02.2021 from https://www.eobuwie.com.pl.

Goodshoes.pl fan page. (2021). Retrieved 02.02.2021 from https://www.facebook.com/ GoodShoespl.

Goodshoes.pl website. (2021). Retrieved 02.02.2021 from https://www.goodshoes.pl.

Grąbczewska, K. (2019). Zastosowanie mediów społecznościowych w komunikacji marketingowej na przykładzie portalu Facebook. [Bachelor's thesis, Nicolaus Copernicus University, Toruń].

Hoberg, G., Phillips, G., \& Prabhala, N. (2014). Product market threats, payouts, and financial flexibility. The Journal of Finance, 69(1), 293324. https://doi.org/10.1111/jofi.12050.

Idrysheva, Z., Tovma, N., Abisheva, K., Murzagulova M., \& Mergenbay, N. (2019). Marketing communications in the digital age. E3S Web of Conferences, 135, 04044. https://doi. org/10.1051/e3sconf/201913504044.

Izakova, N., Kapustina, L., \& Drevalev, A. (2021). Performance of social media marketing communications of industrial companies. SHS Web of Conferences, 93, 03027. https://doi. org/10.1051/shsconf/20219303027. 
Keller, K.L. (1993). Conceptualizing, measuring, and managing customer-based brand equity. Journal of Marketing, 57(1), 1-22. https://doi. org/10.2307/1252054.

Lam, S.Y., Venkatesh, S., Erramilli, M.K., \& Bvsan, M. (2003). Customer value, satisfaction, loyalty, and switching costs: an illustration from a business-to-business service context. Journal of the Academy of Marketing Science, 32(3), 293-311. https:// doi.org/10.1177/0092070304263330.

Ławrowski, P. (2020). Jakie cechy powinna mieć nowoczesna strona internetowa każdej firmy? In T. Bonek (Ed.), Projektowanie stron internetowych ie-sklepów (pp. 21-31). Interaktywnie. com.

Moisescu, O.I. (2009). The importance of brand awareness in consumers' buying decision and perceived risk assessment. Management $\mathcal{E}$ Marketing, 7(1), 103-110.

Niepewna, U. (2021). Understand customer loyalty with the Apostle model. Retrieved 01.03.2021 from https://blog.startquestion.com.

Opineo.pl. (2021a). Opinions about Buu.pl. Retrieved 02.02.2021 from https://www.opineo.pl/ opinie/buu-pl.

Opineo.pl. (2021b). Opinions about Czasnabuty.pl. Retrieved 02.02.2021 from https://www.opineo.pl/opinie/czasnabuty-pl.

Opineo.pl. (2021c). Opinions about Deezee.pl. Retrieved 02.02.2021 from https://www.opineo. pl/opinie/deezee-pl.

Opineo.pl. (2021d). Opinions about Eobuwie.pl. Retrieved 02.02.2021 from https://www.opineo. $\mathrm{pl} /$ opinie/eobuwie-pl.

Opineo.pl. (2021e). Opinions about Goodshoes.pl. Retrieved 02.02.2021 from https://www.opineo. $\mathrm{pl} /$ opinie/goodshoes-pl.

Opineo.pl. (2021f). Opinions about Runcolors.pl. Retrieved 02.02.2021 from https://www.opineo. $\mathrm{pl} /$ opinie/runcolors-pl.

Patil, P.H. (2017). Brand awareness and brand preference. International Research Journal of Management and Commerce, 4(7), 15-24.

Runcolors.pl fan page. (2021). Retrieved 02.02.2021 from https://www.facebook.com/RunColors.

Runcolors.pl website. (2021). Retrieved 02.02.2021 from https://runcolors.pl.
Sellyo.pl fan page. (2021). Retrieved 02.02.2021 from https://www.facebook.com/sellyoPL.

Sellyo.pl website. (2021). Retrieved 02.02.2021 from https://sellyo.pl.

Shafiee, M.M., \& Bazargan, N.A. (2018). Behavioral customer loyalty in online shopping: the role of e-service quality and e-recovery. Journal of Theoretical and Applied Electronic Commerce Research, 13(1), 26-38. https://doi. org/10.4067/s0718-18762018000100103.

Strzelecki, A. (Ed.). (2014). Google Analytics: 42 panele informacyjne, Czesść I. Retrieved 01.03.2016 from http://www.silesiasem.pl.

Utz, S., Kerkhof, P., \& van den Bos, J. (2012). Consumers rule: how consumer reviews influence perceived trustworthiness of online stores. Electronic Commerce Research and Applications, 11(1), 49-58. https://doi.org/10.1016/j. elerap.2011.07.010.

van Riel, A.C.R., Lemmink, J., Streukens, S., \& Liljander, V. (2004). Boost customer loyalty with online support: the case of mobile telecoms providers. International Journal of Internet Marketing and Advertising, 1(1), 4. https://doi. org/10.1504/ijima.2004.003687.

$\mathrm{Xu}$, A., Liu, Z., Guo, Y., Sinha, V., \& Akkiraju, R. (2017). A new chatbot for customer service on social media. Proceedings of the 2017 CHI Conference on Human Factors in Computing Systems, 3506-3510. https://doi. org/10.1145/3025453.3025496.

Żurek, J. (2020). Rynek obuwia w e-commerce. Retrieved 02.02.2021 from https://blog.arvato.pl.

\section{Acknowledgements}

Author contributions: author have given approval to the final version of the article.

Funding: this research was fully funded by the author's own sources.

Note: the results of this study were presented at 11th International Conference on Applied Economics Contemporary Issues in Economy (June 17-18, 2021, online, Poland). 


\section{Appendix}

Table 1.

Correlation between the frequency of seeing marketing messages by respondents and their market behaviour

\begin{tabular}{|c|c|c|c|c|c|}
\hline & $\begin{array}{l}\text { the spontaneous } \\
\text { brand awareness }\end{array}$ & $\begin{array}{c}\text { the aided brand } \\
\text { awareness }\end{array}$ & $\begin{array}{l}\text { the frequency of store } \\
\text { website visits by recipients }\end{array}$ & $\begin{array}{l}\text { the propensity } \\
\text { to repurchase }\end{array}$ & $\begin{array}{l}\text { store } \\
\text { reviews }\end{array}$ \\
\hline $\begin{array}{l}\text { the frequency of seeing } \\
\text { of marketing content by } \\
\text { recipients }\end{array}$ & 0.9464 & 0.9940 & 0.9107 & 0.9345 & 0.9940 \\
\hline
\end{tabular}

Source: Own preparation. 


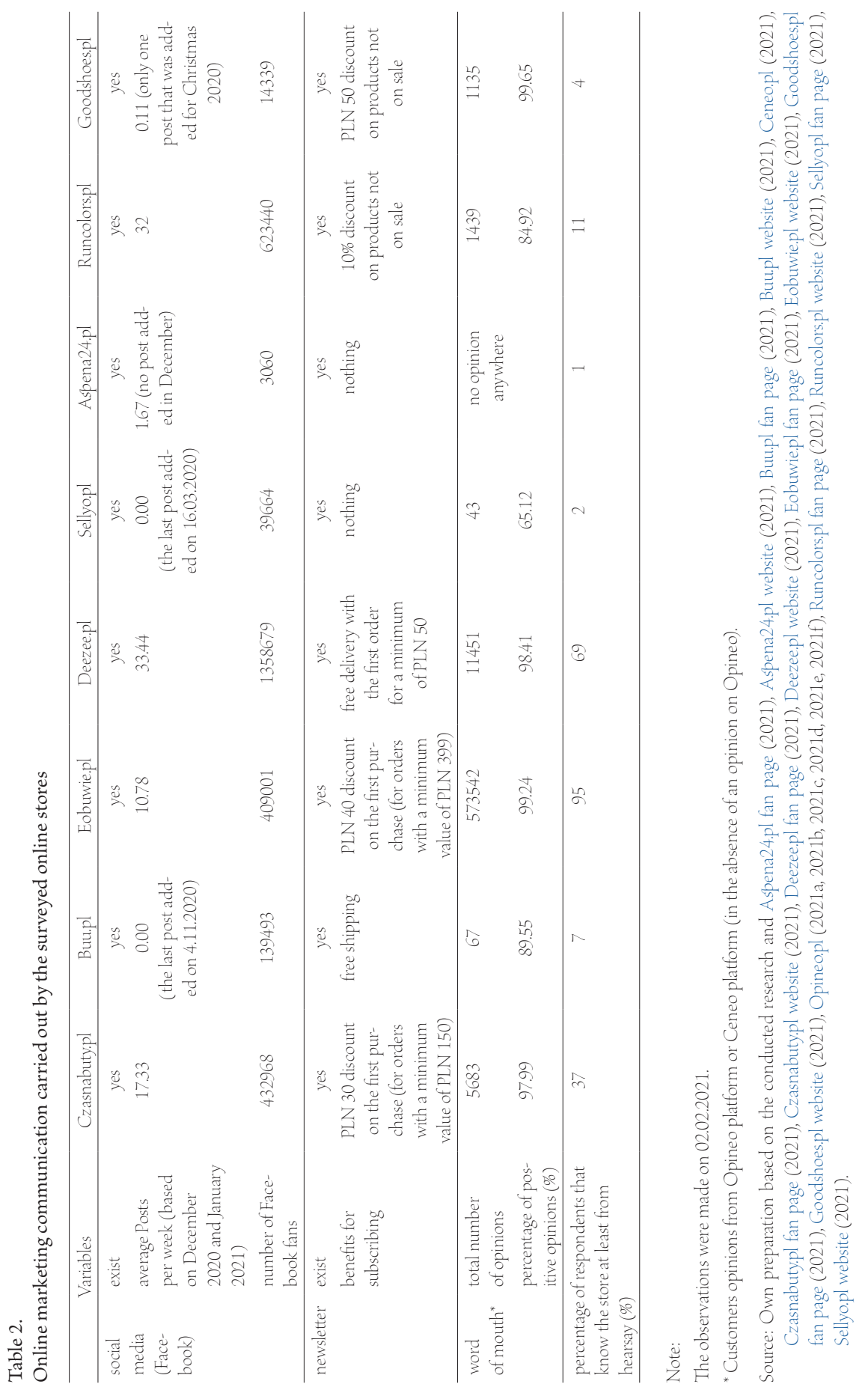


